\title{
Surface quality of hardened steels after grinding
}

Martin Novak, MSc., Ph.D. Faculty of Production Technology and Management, J. E. Purkyne University in Usti nad Labem. Czech Republic. E-mail: novak@fvtm.ujep.cz.

Problems about hardened steels grinding is presently very important part of engineering. Many applications of these materials using in practice, machine, devices and in different industry like automotive, aviation, cosmonautics and in area of health, safety and protection of passengers in vehicles, planes, aircrafts, ships, trains and many others. Because of these areas that used the passengers is very important surface quality and durability of these parts of machines. Topic of surface quality changes in working of the parts is especially important in dynamic load parts. These parts are very loaded by alternating stress in cases of double axis stress (torsion and bend). Such materials are for example bearing, shafts and gears. In all cases the production technology influences surface quality.

Keywords: Cutting Conditions, Grinding, Microstructure, Residual Stress, Surface Quality

\section{Acknowledgement}

This experiment appears by means of specific research of J. E. Purkyne University deals with automotive parts machining.

\section{References}

[1] BASSOLI, E. etc. Grinding Micromechanisms of a Sintered Friction Material, in: Journal of Manufacturing Science and Engineering, ASME, Feb 2011, vol. 133., 2011, 6 p.

[2] CERNY, V., POSPISIL, L. Brusivo a brusne nastroje, SNTL, Praha, 1967.

[3] HOLESOVSKY, F., NOVAK, M. Influence of grinding on machine parts with desing notches, in: Manufacturing Technology IX, UJEP, Usti n. Labem, 2010, p. 40-46.

[4] JUSKO, O. Vyvoj a inovace brousicich nastroju, in: Strojirenska technologie, vol. XV., no. 1, UJEP, Usti n. Labem, 2010, p. 17-22.

[5] KOCMAN, K. Analyza vyvojovych brousicich kotoucu na bazi mikrokrystalickeho korundu, in: Strojirenska technologie, vol. XV., no. 3., UJEP, Usti nad Labem, 2010, p. 40-47.

[6] LUKOVICS, I., BILEK, O., HOLEMY, S. Development of Grinding Wheels for Tools Manufacturing, in: Manufacturing Technology, vol. X., no. 10., UJEP, Usti nad Labem, 2010, p. 10-16.

[7] MADL, J., HOLESOVSKY, F., etc.: Integrita obrobenych povrchu z hlediska funkcnich vlastnosti, Usti n. Labem, FVTM UJEP, Usti nad Labem, 2008.

[8] NOVAK, M., HOLESOVSKY, F. Vliv brousiciho nastroje na kvalitu povrchu a povrchove vrstvy. ITC 2009 - VII., In Proceedings of International Tools Conference, Zlin, Czech Republic, 2009.

[9] NOVAK, M. Integrita povrchu pri brouseni kalenych oceli. Disertacni prace. FVTM UJEP. 2011. 168 p.

[10] NOVAK, M., HOLESOVSKY, F. Problematika brouseni hlinikovych slitin, in: Transaction of Universities of Kosice, 4/2009, Kosice, 2009.

[11] RUZICKA, L., MADL, J. Optimalizace reznych podminek pri vyrobe hydraulickych valcu. In Strojirenska technologie, XVI., c. 2. FVTM UJEP. 2011. 34-38 p.

[12] VASILKO, K. Kvantifikace a analyza presneho a vysoce produktivniho soustruzeni. In Strojirenska technologie, XIV., c. 3. FVTM UJEP. 2009. 25-33 p. 